\title{
Senecavirus $A$ (SVA) in finishing swine: diagnosis and viral isolation
}

\author{
Manuela Muller ${ }^{\text {(D) Vinícius Borges Faria }}{ }^{2}$ (D) Sergio Abreu Machado ${ }^{3}$ (D) Mathias Martins $^{4^{*}}$ (D)
}

\footnotetext{
${ }^{1}$ Curso de Medicina Veterinária, Laboratório de Virologia, Universidade do Oeste de Santa Catarina (Unoesc), Xanxerê, SC, Brasil. ${ }^{2}$ Laboratório Inata Produtos Biológicos, Uberlândia, MG, Brasil.

${ }^{3}$ Laboratório de Biologia Molecular, Medicina Veterinária, Programa de Pós-graduação em Sanidade e Produção Animal, Universidade do Oeste de Santa Catarina (Unoesc), Xanxerê, SC, Brasil.

${ }^{4}$ Laboratório de Virologia, Medicina Veterinária, Programa de Pós-graduação em Sanidade e Produção Animal, Universidade do Oeste de Santa Catarina (Unoesc), 89820-000, Xanxerê, SC, Brasil. E-mail: mathiasmartinsmv@gmail.com *Corresponding author
}

ABSTRACT: Senecavirus A (SVA) has been a problem in Brazil since the end of 2014. The infections caused by SVA have disrupted the productive chain in Brazil, as it can be confused with foot-and-mouth disease. Although, the virus has remained endemic in the country, an increase in the number of cases of the disease was observed in 2018. The aim of the present study was to conduct the differential diagnosis of foot-and-mouth disease in an outbreak of vesicular disease in finishing swine. Animals (160-170 days old) were kept on a farm with 6000 pigs in Minas Gerais State, Brazil. The morbidity and mortality rates were $20 \%$ and 2.2\%, respectively. The diagnosis was performed by RT$P C R$, using primers that determine the amplification of an internal region of the $3 D$ gene. Furthermore, samples were inoculated into BHK-21 cell culture for viral isolation. In the first passage under cultivation, a cytopathogenic effect compatible with SVA replication (rounding and detachment of the cell monolayer) was observed. The viral identity was confirmed using two additional assays: indirect immunofluorescence assay (IFA) and nucleotide sequencing. Both tests confirmed that the infection was caused by SVA. In summary, we described a method for the diagnosis and viral isolation of SVA, a virus that arrived in Brazil in 2014 and has become endemic in the country.

Key words: emerging diseases, idiopathic vesicular disease, picornavirus, Seneca Valley virus, vesicular disease.

Senecavirus $A$ (SVA) em suínos de terminação: diagnóstico e isolamento viral

RESUMO: Senecavirus A (SVA) é um problema no Brasil desde o final de 2014. As infecções causadas pelo SVA têm causado problemas para a cadeia produtiva no Brasil, pois podem ser confundidas com febre aftosa. Embora o vírus permaneça endêmico no país, foi observado um aumento no número de casos em 2018. O objetivo do presente estudo foi realizar o diagnostico diferencial de febre aftosa em um surto de doença vesicular em suínos de terminação. Os animais (160 a 170 dias de idade) eram mantidos em uma granja com 6.000 suínos no estado de Minas Gerais, Brasil. As taxas de morbidade e mortalidade foram de 20\% e 2,2\%, respectivamente. O diagnostico foi realizado por RT-PCR, utilizando primers que determinam a amplificação de uma região interna do gene $3 D$. Além disso, as amostras foram inoculadas na cultura de células BHK-21 para isolamento viral. Na primeira passagem em cultivo, foi observado efeito citopatogênico compativel com a replicação do SVA (arredondamento e descolamento da monocamada celular). A identidade viral foi confirmada usando duas técnicas adicionais: ensaio de imunofluorescência indireta (IFA) e sequenciamento de nucleotídeos. Ambos os testes confirmaram que a infecção foi causada por SVA. Em resumo, descrevemos um método para o diagnóstico e isolamento viral do SVA, um vírus que chegou ao Brasil em 2014 e se tornou endêmico no país.

Palavras-chave: doenças emergentes, doença vesicular, doença vesicular idiopática, picornavírus, Seneca Valley virus.

In 2002, Seneca Valley virus (SVV) was first described as a cell culture contaminant in the United States (HALES et al., 2008). In 2014, SVV was renamed as Senecavirus $A$ (SVA). The SVA is a virus with an RNA genome that belongs to the Senecavirus genus and Picornaviridae family (ICTV, 2018). In piglets up to 7 days old, SVA infection has been linked to diarrhea, multifocal vesicles around the hooves and snout, anorexia, lethargy, neurological signs, and mortality (LEME et al., 2015). In adult animals, mainly breeding and finishing animals, the manifestations are vesicles and erosions in the oral cavity, snout, and coronary band of the hooves
(JOSHI et al., 2016a; MONTIEL et al., 2016). Thus, pigs affected by SVA have mobility issues, which compromise animal performance and welfare (FERNANDES et al., 2018; MONTIEL et al., 2016).

In Brazil, SVA became a problem in late 2014, when it was detected in piglets experiencing vesicular disease, diarrhea, and death, and in adult animals experiencing the occurrence of vesicles (LEME et al., 2015). Although the virus has remained endemic in the country since, field veterinarians reported an increase in the number of cases of the disease between late 2018 and early 2019, especially in finishing swine. 
The SVA has created problems for the swine production chain in Brazil, since it is a vesicular disease that can be confused with foot-andmouth disease (LEME et al., 2019). However, there is little research concerning this virus in Brazil. Thus, the objective of the present study was to conduct the differential diagnosis of foot-and-mouth disease in an outbreak of vesicular disease in finishing pigs.

In May 2019, finishing swine (from 160 to 170 days old) kept on a farm with approximately 6000 pigs in the state of Minas Gerais, Brazil, showed clinical signs compatible with SVA infection. Clinical findings included vesicles, ulcers, and lameness (Figure 1). During the outbreak, the morbidity and mortality rates were $20 \%$ and $2.2 \%$, respectively. After the suspicion of foot-and-mouth disease was ruled out by the official veterinary service, vesicle swabs from five animals were placed into $15 \mathrm{~mL}$ conical centrifuge tubes, frozen, and sent to the laboratory for investigation into the suspected SVA.

For the laboratory diagnosis, $2 \mathrm{~mL}$ of phosphate-buffered saline (PBS) was added to each tube containing a swab. Using a vortex, the tubes were shaken for 20 to $30 \mathrm{~s}$, with $100 \mu \mathrm{L}$ of the supernatant being used for RNA purification using
TRIzol reagent ${ }^{\circledR}$ (Thermo Fisher Scientific ${ }^{\mathrm{TM}}$, USA), following the manufacturer's instructions. Then, the complementary DNA (cDNA) was synthesized using kit SuperScript III reverse transcriptase ${ }^{\circledR}$ (Thermo Fisher Scientific ${ }^{\mathrm{TM}}$, USA), according to the manufacturer's instructions. For the PCR, using software Clone Manager Basic - Sci-Ed, forward and reverse initiators were determined (SVA-3D-F 5' <TGAACCTGCTGTGTTGTC> 3' and SVA3D-R 5' <CAGAGTAGTCACCGTCTAAG $>$ 3', respectively) that delimit the amplification of an internal region of the 3D gene of the SVA genome (product size $359 \mathrm{bp}$ ). The conditions used in the PCR were as follows: $95{ }^{\circ} \mathrm{C}$ for $5 \mathrm{~min}$ for denaturation, followed by 35 cycles of $94^{\circ} \mathrm{C}$ for $30 \mathrm{~s}$ for denaturation, $48{ }^{\circ} \mathrm{C}$ for $30 \mathrm{~s}$ for primer annealing, $72{ }^{\circ} \mathrm{C}$ for $30 \mathrm{~s}$ for extension, and a final extension at $72{ }^{\circ} \mathrm{C}$ for $10 \mathrm{~min}$. The PCR products were resolved by electrophoresis $(80 \mathrm{~V}, 40 \mathrm{~min}$ ) on agarose gel $1 \%$, and the DNA was intercalated with Unisafe ${ }^{\circledR}$ (Unisafe Dye, Uniscience do Brasil, Brazil) and visualized in a gel imaging system under UV light (ChemiDoc MP, BioRad, USA).

After adding PBS, the tubes containing the swabs were centrifuged for $10 \mathrm{~min}$ at $5000 \mathrm{RPM}$ and $4{ }^{\circ} \mathrm{C}$, and the supernatant was used for inoculation in

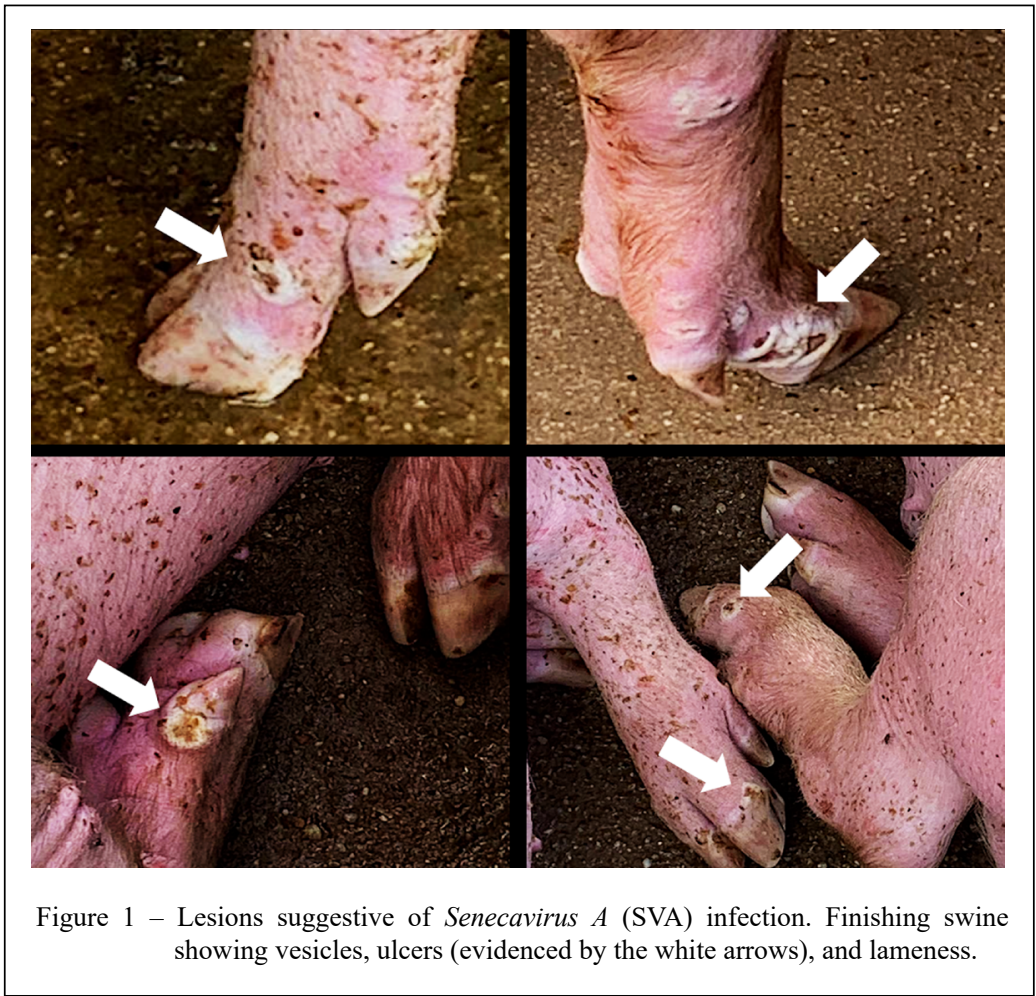

Ciência Rural, v.50, n.7, 2020. 
cell culture. Baby hamster kidney cells (BHK-21 [C $\left.13 \mathrm{ATCC}^{\circledR} \mathrm{CCL}-10^{\mathrm{TM}}\right]$ ) were cultured in 6-well plates, prepared $24 \mathrm{~h}$ in advance, and inoculated with 500 $\mu \mathrm{L}$ of the swab supernatant from the lesions. After $1 \mathrm{~h}$ of adsorption, the inoculum was replaced with a culture medium (MEM) supplemented with 5\% fetal bovine serum (SFB), L-glutamine $(2 \mathrm{mM})$, penicillin (100 U.mL $\left.{ }^{-1}\right)$, and streptomycin $\left(100 \mu \mathrm{g} \cdot \mathrm{mL}^{-1}\right)$. The cultures were kept in an incubator at $37{ }^{\circ} \mathrm{C}$ in a $5 \%$ $\mathrm{CO}_{2}$ atmosphere for $48 \mathrm{~h}$.

Cell cultures were subjected to the indirect immunofluorescence assay. Quickly, inoculated and uninoculated cells (negative control) grown on multispot slides were fixed and permeabilized with acetone PA for $5 \mathrm{~min}$. An anti-SVA monoclonal antibody $(\mathrm{mAb})$ (dilution 1:1000) (kindly provided by Dr. D. Diel) was incubated for $1 \mathrm{~h}$ at $37^{\circ} \mathrm{C}$. Then, an antimouse-IgG-FITC conjugated antibody (dilution 1:200) (Sigma-Aldrich, USA) was incubated in similar conditions. The reading was performed using an epifluorescence microscope $\left(\right.$ Opticam $\left.{ }^{\circledR}\right)$.

For nucleotide sequencing, the RTPCR product was purified using a Purification Kit (PureLink $^{\mathrm{TM}}$ Quick Gel Extraction and PCR Purification Combo Kit Purification, Invitrogen ${ }^{\mathrm{TM}}$, USA), following the manufacturer's instructions.
The positive samples in the cell culture isolation were sequenced in quadruplicate in an automatic sequencer (ABI-PRISM 3100 Genetic Analyzer, Applied Biosystems, Foster City, CA) using the BigDye reagent.

The sequences were analyzed using the Staden Package program to obtain the consensus sequence, which was subsequently submitted to the BLAST sequence analysis tool for comparison with sequences available on GenBank, using the NCBI (National Center for Biotechnology Information) database. Sequence alignment was performed with ClustalW, an internal feature of the BioEdit software. The obtained sequence was aligned with 24 sequences available on GenBank using the BioEdit Sequence Alignment Editor Software, version 7.0.5.3 (http:// www.mbio.ncsu.edu/bioedit/bioedit.html). The phylogenetic tree was built using the neighbor-joining method, with 1000 self-initialization replicates, based on the kimura-2 parameter of nucleotide substitution in MEGA6 (TAMURA et al., 2013).

The suspicion of SVA was confirmed by RT-PCR after the amplification of a product with the predicted molecular weight (359 bp) (Figure 2). The five samples analyzed using RTPCR tested positive. However, in cell culture

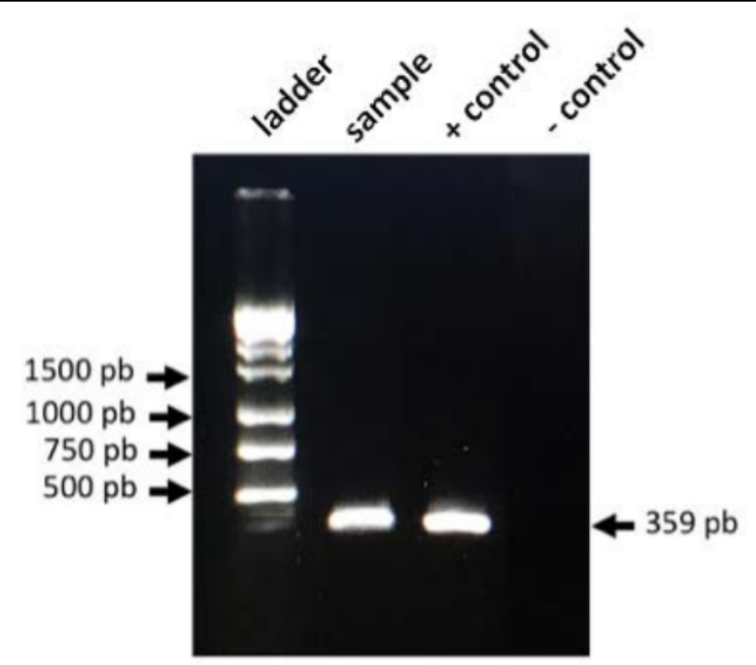

Figure 2 - Agarose gel after reverse transcription followed by polymerase chain reaction (RT-PCR) for Senecavirus $A$ (SVA). Amplification of an internal region of the gene encoding the $3 \mathrm{D}$ protein $(359 \mathrm{bp})$. 
isolation (CCI), only one of the five samples tested positive. Probably because some of these samples have lost viability (lost infectivity), but the genome has been preserved, making it possible positive result in RT-PCR. After the first pass in cell culture, a cytopathogenic effect compatible with SVA replication was observed (rounding and detachment of the cellular layer) approximately $24 \mathrm{~h}$ post-infection (Figure 3 ). The identity of the isolated virus was confirmed using an indirect immunofluorescence assay (IFA) (Figure 4). The use of an $\mathrm{mAb}$ against SVA ensured the specificity of the diagnostic tool. In addition, genetic sequencing and phylogenetic analysis grouped the sample obtained in the present study with Brazilian SVA sequences available on GenBank (Figure 5). Thus, both tests confirmed the identity of the virus causing the vesicular disease during the investigated outbreak. In addition, the isolation of an SVA sample makes it possible to carry out studies in vitro and in vivo viral characterization.

Clinically identifying SVA infections remains a challenge. In the first cases in Brazil, piglets were the main category affected and, in addition to the vesicular disease, the animals presented diarrhea, neurological signs (motor incoordination, tremors, and convulsion), and mortality (LEME et al., 2015). In finishing swine, vesicular disease is the main manifestation of the infection and the animals usually recover within two weeks (JOSHI et al., 2016a). From the first detection in 2014 until 2019, SVA has remained endemic in the main swine-producing regions in Brazil. Although, the frequency of the disease has fluctuated and remained low, in late 2018 and early 2019 there was an intense increase in the occurrence of outbreaks (LEME et al., 2019). In addition, the attention of veterinarians and researchers has been drawn, as the outbreaks of SVA started to occur mainly in finishing pigs, which is different from what was described in the first cases in Brazil.

In Brazil, since the first viral detection in 2014, there has been much speculation concerning how the virus has been maintained and circulated among farms. Recently, research has shown the ability of SVA to remain in the infected animals, with carriers of the virus able to spread the agent among herds via viral excretion up to 60 days post-infection (MAGGIOLI et al., 2019). This hypothesis may explain the maintenance of the virus and increase in cases observed in Brazil between late 2018 and early 2019. In addition, a study has detected SVA in environmental samples, as well as the feces and
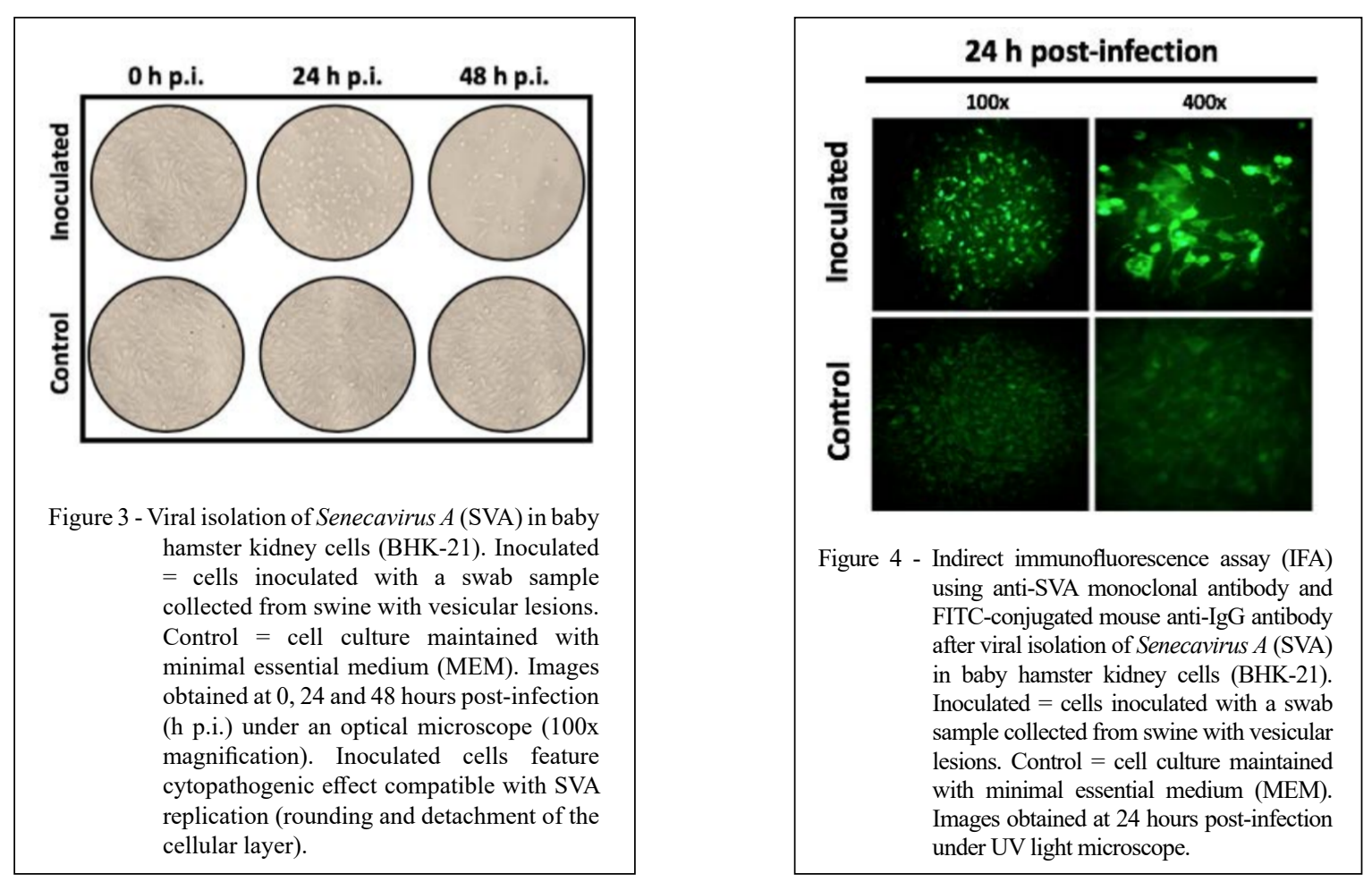

Ciência Rural, v.50, n.7, 2020. 


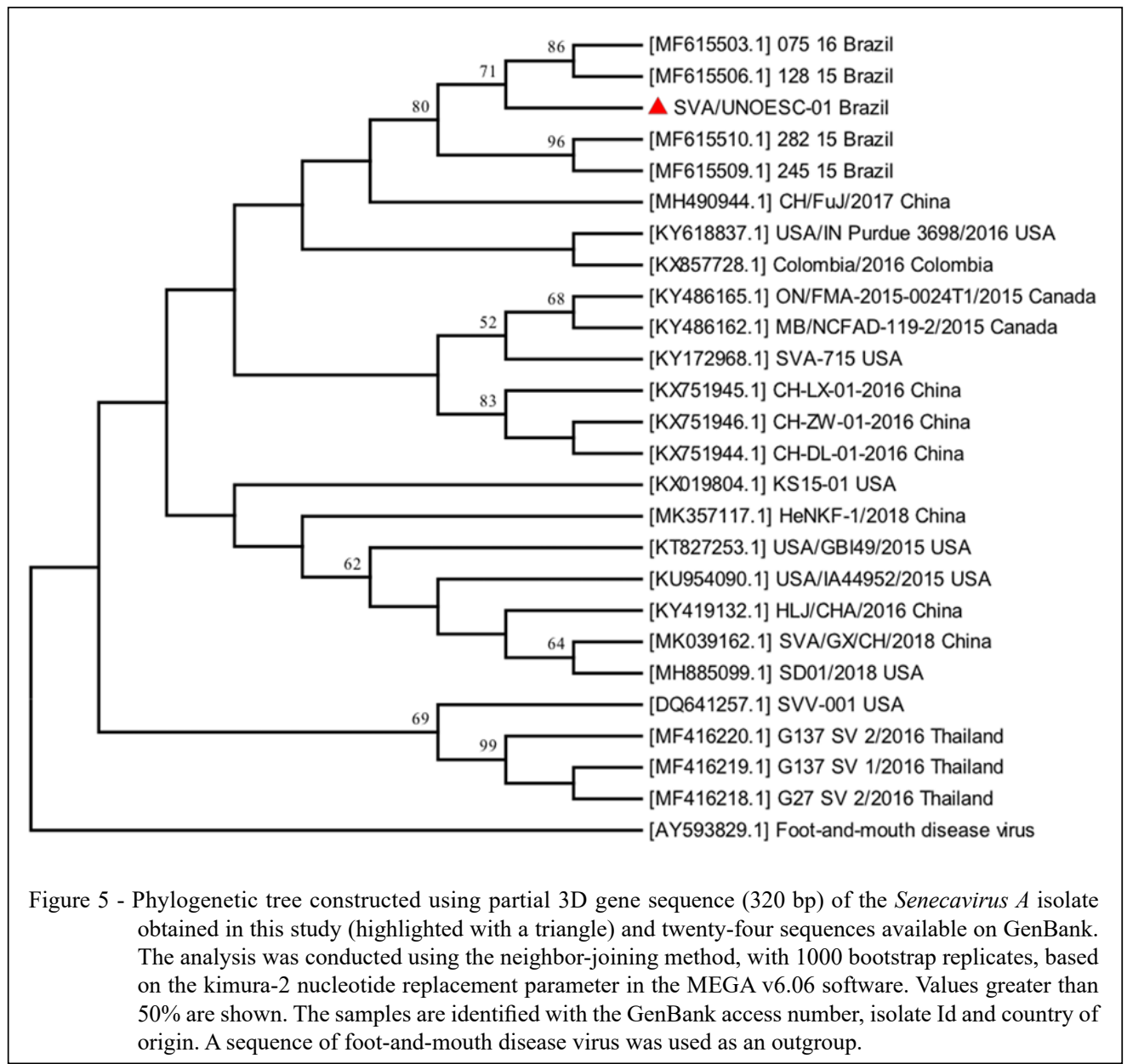

intestines of mice in swine farms with a history of the disease (JOSHI et al., 2016b). Another possibility for the national increase in SVA cases, is the replacement of swine populations immune to the virus. After extensive viral circulation within swine herds in 2015, herds became immune to SVA. However, the breeding populations were gradually replaced and the population/herd immunity was lost. Although, SVA has become a challenge for pig farming in several countries in Asia and America, so far there is no licensed vaccine in any of the main pig producing countries (YANG et al., 2018).

In summary, SVA has caused problems for the production chain in Brazil. We performed the differential diagnosis of foot-and-mouth disease in an outbreak of vesicular disease in finishing swine. The SVA diagnosis was confirmed and a contemporary strain from finishing swine was isolated.

\section{BIOETHICS \\ AND \\ COMMITTEE APPROVAL}

Animal sample used in this study were collected as part of routine diagnostics. This article does not contain studies with human or animal participants carried out by any of the authors.

\section{DECLARATION OF CONFLICT OF} INTERESTS

The authors declare no conflict of interest. The founding sponsors had no role in the design of the study; in the collection, analyses, or interpretation of data; in the writing of the manuscript, and in the decision to publish the results.

\section{ACKNOWLEDGEMENTS}

This study was financed in part by the Coordenação de Aperfeiçoamento de Pessoal de Nível Superior (CAPES), Brasil - Finance code 001. 


\section{AUTHORS' CONTRIBUTIONS}

MM, VBF, and MM performed the analyses. All authors critically reviewed the manuscript and approved the final version.

\section{REFERENCES}

HALES, L.M. et al. Complete genome sequence analysis of Seneca Valley virus-001, a novel oncolytic picornavirus. Journal of general virology, v.89, p.1265-1275, 2008. Available from: $<$ http://jgv.microbiologyresearch.org/pubmed/content/journal/ jgv/10.1099/vir.0.83570-0>. Accessed: Dec. 24, 2019. doi: 10.1099/vir.0.83570-0.

FERNANDES, M.H.V. et al. Pathogenicity and cross-reactive immune responses of a historical and a contemporary Senecavirus A strains in pigs. Virology, v.522, p.147-57, 2018. Available from: $\quad<$ https://www.sciencedirect.com/science/article/pii/ S0042682218301818?via\%3Dihub>. Accessed: Dec. 24, 2019. 10.1016/j.virol.2018.06.003.

ICTV. Virus Taxonomy: 2018 Release. Washington, DC (2018). Available from: <https://talk.ictvonline.org/ictv-reports/ ictv_online_report/positive-sense-rna-viruses/picornavirales/w/ picornaviridae/702/genus-senecavirus $<$. Accessed: Dec. 24, 2019.

JOSHI, L.R. et al. Pathogenesis of senecavirus A infection in finishing pigs. Journal of general virology. v.97, p.3267-3279, 2016a. Available from: <http://jgv.microbiologyresearch.org/ pubmed/content/journal/jgv/10.1099/jgv.0.000631>. Accessed: Dec. 24, 2019. doi: 10.1099/jgv.0.000631.

JOSHI, L.R. et al. Detection of the emerging picornavirus Senecavirus A in pigs, mice, and houseflies. Journal of Clinical Microbiology, v.54, p.1536-45, 2016b. Available from: <https:// jcm.asm.org/content/54/6/1536.short>. Accessed: Dec. 24, 2019. 10.1128/JCM.03390-15.
LEME, R.A. et al. Senecavirus a: an emerging vesicular infection in brazilian pig herds. Transboundary and emerging disease, v.62, p.603-611, 2015. Available from: $<$ https://onlinelibrary.wiley. $\mathrm{com} / \mathrm{doi} /$ full $/ 10.1111 /$ tbed.12430? casa token=7p65J-xVKP4AA AAA\%3AyGm84hahVbUtbXYNA6Rs5wdKbd0ArZLkUTV5fZ bVGaWTH-y1THnJoTrkYxapZQvMyHTz6gdBLq9TLdVWPg>. Accessed: Dec. 24, 2019. 10.1111/tbed.12430.

LEME, R.A. et al. A new wave of Seneca Valley virus outbreaks in Brazil. Transboundary and emerging disease, v.66, p.11011104, 2019. Available from: <https://onlinelibrary.wiley.com/doi/ abs/10.1111/tbed.13151>. Acessed: Dec. 24, 2019. doi: 10.1111/ tbed.13151.

MAGGIOLI, M.F. et al. Persistent infection and transmission of senecavirus a from carrier sows to contact piglets. Journal of virology, v.93, e00819-19, 2019. Available from: < https://jvi.asm. org/content/93/21/e00819-19.abstract>. Accessed: Dec. 24, 2019. doi: 10.1128/JVI.00819-19.

MONTIEL, N. et al. Vesicular disease in 9-week-old pigs experimentally infected with Senecavirus A. Emerging infectious disease, v.22, p.1246-1248, 2016. Available from: $<$ https://www.ncbi.nlm.nih.gov/pmc/articles/PMC4918149/>. Accessed: Dec. 24, 2019. doi: 10.3201/eid2207.151863.

TAMURA K. et al. MEGA6: molecular evolutionary genetics analysis version 6.0. Molecular biology and evolution, v.30, p.2725-2729, 2013. Available from: < https://academic.oup.com/ mbe/article/30/12/2725/1017851>. Accessed: Jan. 2, 2020. doi: $10.1093 / \mathrm{molbev} / \mathrm{mst} 197$.

YANG, F. et al. Immunogenicity and protective efficacy of an inactivated cell culture-derived Seneca Valley virus vaccine in pigs. Vaccine, v.36, p.841-846, 2018. Available from: $\quad<$ https://www.sciencedirect.com/science/article/pii/ S0264410X17318169>. Accessed: Dec. 24, 2019. doi: 10.1016/j. vaccine.2017.12.05. 